\title{
Open lateral internal anal sphincterotomy under local anesthesia as the gold standard in the treatment of chronic anal fissures. A prospective clinical and manometric study
}

\author{
A. Sánchez Romero, A. Arroyo Sebastián, F. Pérez Vicente, P. Serrano Paz, F. Candela Polo, A. Tomás Gómez, \\ D. Costa Navarro, A. Fernández Frías and R. Calpena Rico
}

General Surgery Department and Service of Digestive Diseases. Hospital General Universitario. Elche. Alicante, Spain

Sánchez Romero A, Arroyo Sebastián A, Pérez Vicente F, Serrano Paz P, Candela Polo F, Tomás Gómez A, Costa Navarro $D$, Fernández Frías A, Calpena Rico R. Open lateral internal anal sphincterotomy under local anesthesia as the gold standard in the treatment of chronic anal fissures. A prospective clinical and manometric study. Rev Esp Enferm Dig 2004; 96: 856-863.
The difference in mean squeeze pressure (MSP) between incontinent patients and continent patients was not statistically significant.

Conclusions: open sphincterotomy under local anesthesia has a long-term rate of healing and a morbidity rate similar to other techniques. It may therefore be considered an effective treatment for chronic anal fissure.

Key words: Chronic anal fissure. Internal sphincterotomy. Anal manometry.

\section{INTRODUCTION}

Background: chronic anal fissure is one of the most frequent proctological disorders in Western populations. Open lateral internal sphincterotomy is one of the therapeutic options accepted as the treatment of choice for chronic anal fissure, since it reduces the hypertonia of the internal anal sphincter (the main etiopathogenic mechanism of fissures), decreases anal pain, and allows the fissure to heal.

Material and methods: we carried out a prospective study of 120 patients operated on for chronic anal fissure with open sphincterotomy under local anesthesia at our Proctology Outpatient Unit from 1998 to 2001. No preoperative studies, bowel preparation, or antibiotic prophylaxis were carried out. All patients were followed up after 1 week, 2 months, 6 months, and 1 year, and underwent an anal manometry before and after surgery.

Results: early complications: 3 hematoma-ecchymosis of the wound (2.5\%), 3 self-limited hemorrhage events (2.5\%). No hemorrhoidal thrombosis, fistulas, or perianal abscesses occurred. Fissures recurred in nine patients $(7.5 \%)$ within one year. The initial rate of incontinence of $7.5 \%$ at two months dropped down to $5 \%$ at six months.

The mean resting pressure (MRP) in incontinent patients was lower than in continent patients $(55 \pm 7 \mathrm{mmHg}$ versus $80.7 \pm 21 \mathrm{mmHg}$ ).

Recibido: 21-11-03.

Aceptado: 28-04-04.

Correspondencia: Ana María Sánchez Romero. Servicio de Cirugía General y Aparato Digestivo. Hospital General Universitario de Elche. C/ Camino de Almazara, 11. 03203 Elche. Alicante. Tel.: 609609 248. Fax: 966 679 377. e-mail: anasanchez2@yahoo.es
Chronic anal fissure (CAF) is one of the most frequent proctological disorders in the Western world, and may sometimes affect the patient's quality of life. Thus, rapid effective treatment is a priority (1-3).

The etiology of this condition is controversial, but it is generally accepted that spasm of the internal anal sphincter plays a fundamental role in its pathogenesis. Therefore there is a vicious circle: fissure - internal anal sphincter spasm pain $(4,5)$. Consequently, internal lateral sphincterotomy (ILS) has been widely accepted as the treatment of choice in chronic anal fissure, since it relaxes the hypertonic sphincter, thereby reducing anal pain and allowing the fissure to heal (6). Open ILS performed under local anesthesia is a rapid effective technique for the treatment of CAF.

We investigated the results of open sphincterotomy performed under local anesthesia in the Outpatient Clinic at our Coloproctology Unit in terms of both fissure healing and postoperative complications.

\section{MATERIAL AND METHODS}

We carried out a prospective study of 120 patients operated on for chronic anal fissure from September 1998 to September 2001 in the Coloproctology Unit, General University Hospital, Elche. Detailed written consent was obtained beforehand. 
The diagnosis of chronic anal fissure was established on clinical examination (visualization), and over 1 month of unsuccessful medical treatment (high residue diet, analgesics, and warm sitz baths). We collected information regarding age, sex, symptoms, bowel habits, findings on examination, and manometric values before surgery. Mean age of patients was 40.45 years (range: $21-74$ ); 42 were women (35\%) and 78 men (65\%); length of symptoms was 17.6 months (range: 1-70). Chronic constipation, anal pain, and bleeding were the symptoms present in over $60 \%$ of patients, as shown in table I.

Table I. Patient demographic characteristics, symptoms and signs before treatment

\begin{tabular}{lc}
\hline Mean age & 40.45 years $(21-74)$ \\
Gender (female/male) & $42(35 \%) / 78(65 \%)$ \\
Lenght of symptoms (months) & $17.60(1-70)$ \\
Location & \\
$\quad$ Mid posterior line & $84(70 \%)$ \\
$\quad$ Mid anterior line & $27(22.5 \%)$ \\
$\quad$ Both & $9(7.5 \%)$ \\
Skin tag & $84(70 \%)$ \\
Anal pain & $108(90 \%)$ \\
Bleeding & $102(85 \%)$ \\
Constipation & $84(70 \%)$ \\
Pruritus & $60(50 \%)$ \\
Previous anal surgery & $6(4.7 \%)$ \\
Anal hypertonia & \\
$\quad$ Mild & $18(15 \%)$ \\
Moderate & $72(60 \%)$ \\
$\quad$ Unexplorable & $30(25 \%)$ \\
\hline
\end{tabular}

Exclusion criteria included: associated anal pathologies (incontinence, stenosis, abscess, fistula, and hemorrhoids), other comorbidities (IBD, AIDS, tuberculosis, sexually transmitted diseases, and immunodepression), anticoagulant therapy, and documented allergy to local anesthesia.

All patients were operated on by three surgeons specialized in coloproctology. The procedure was performed with the patient in jack-knife position. Patients were monitored with a pulsioximeter. No preoperative studies, bowel preparation, or antibiotics were required. Local anesthesia (20 cc of $2 \%$ mepivacaine) was injected with a $25 \mathrm{G}$ needle, infiltrating the skin, intersphincteric space, internal anal sphincter, and submucosa on the left and right sides, as well as the bed of the fissure.
The right lower anal canal was exposed using an anal retractor, and a 1-2 cm incision made in the skin of the intersphincteric groove. The anal mucosa was separated from the internal anal sphincter up to the dentate line. The intersphincteric space was dissected and the distal internal sphincter was divided using electric diathermy under direct vision. The incision was not closed, and digital direct pressure was applied for 5 minutes. Hospital admission and patient observation were unnecessary. Instructions were given concerning a high-residue diet, analgesics, and warm sitz baths.

The patients were visited in our coloproctology outpatient clinic after 1 week, 2 months, 6 months, and 1 year. We collected information on symptoms, bowel habits, findings on examination, manometric values, early and late complications, healing, and fissure recurrence. Healing was defined as an epithelization of the fissure with absence of symptoms. Continence was determined using the Cleveland Score (Table II).

Anal manometry was done using a water perfusion system (Ardorfer Medical Specialities Inc., Greendale, WI) with a 6-lumen catheter (external diameter, $4 \mathrm{~mm}$ ). Both the mean resting pressure (MRP) and the mean squeeze pressure (MSP) were recorded. Results were then compared to normal values for healthy control patients in our lab: MRP = $66 \pm 23 \mathrm{mmHg}$, and MSP = $164 \pm 60 \mathrm{mmHg}$ (control group). Manometric values were statistically compared using Student's t test.

\section{RESULTS}

Fissures were mostly located in the posterior midline (70\%). In most cases there was a single fissure, with 7 patients having more than one. On physical examination there was a high incidence of associated hypertonia of the sphincter -slight in 18 patients $(15 \%)$, moderate in 72 patients $(60 \%)$, and inexplorable in 30 patients $(25 \%)$ who could not tolerate digital rectal examination-. A "sentinel hemorrhoid or polyp" was found in 84 patients (70\%) as shown in table I.

The complications and results of treatment are shown in table III. After the first week, three patients (2.5\%) had selflimited bleeding of the wound, and ecchymosis was found in other 3 patients $(2.5 \%)$. There were no anal abscesses, perianal fistulas, hemorrhoidal thrombosis, or urine retention, nor was there any admission to hospital due to surgical complications.

Table II. Cleveland Score

\begin{tabular}{lcccc}
\hline Type of incontinence & Never & Rarely & Sometimes & Usually \\
\hline Solid stools & 0 & 1 & 2 & 3 \\
Liquid stools & 0 & 1 & 2 & 3 \\
Gas & 0 & 1 & 2 & 3 \\
Wears pad & 0 & 1 & 2 & 3 \\
Altered lifestyle & 0 & 1 & 2 & 3 \\
\hline
\end{tabular}

Never, no episodes of incontinence; rarely, less than once per month; sometimes, more than once per month; usually, one or more episodes per week but less than daily; always, more than one episode per day. The score is calculated by adding the highest value for the type of incontinence to a 0-4 point evaluation of lifestyle so that it can range from 0 (normal continence) to a maximum of 20 (maximal incontinence with maximal disturbance of lifestyle). 
Table III. Complications and results of treatment

\begin{tabular}{|c|c|}
\hline Ecchymosis & $3(2.5 \%)$ \\
\hline Hemorrhage & $3(2.5 \%)$ \\
\hline Anal abscess or fistula & $0 \%$ \\
\hline $\begin{array}{l}\text { Hemorrhoidal thrombosis } \\
\text { Incontinence }\end{array}$ & $0 \%$ \\
\hline 2 months & $\begin{array}{r}9(7.5 \%) \ldots \text { to flatus } 2(1.7 \%) \\
\text { to liquid } 3(2.5 \%) \\
\text { to solid stool } 4(3.3 \%)\end{array}$ \\
\hline 6 months & $6(5 \%)$ \\
\hline 1 year & $6(5 \%)$ \\
\hline \multicolumn{2}{|l|}{ Recurrence } \\
\hline 2 months & $3(2.5 \%)$ \\
\hline 6 months & $3(2.5 \%)$ \\
\hline 1 year & $3(2.5 \%)$ \\
\hline Overall & $9(7.5 \%)$ \\
\hline
\end{tabular}

After 2 months, fissure persistence or recurrence was found in 3 patients $(2.5 \%)$. With regard to incontinence, 3 patients $(2.5 \%)$ were found to be incontinent to fluids, 2 patients $(1.66 \%)$ had sporadic incontinence to flatus, and 4 patients $(3.33 \%)$ had occasional incontinence to stools. The overall rate of incontinence was 7.5\%. At revision after 6 months, fissure recurrence was found in another 3 patients $(2.5 \%)$. Incontinence reverted in three patients at 2 months' follow-up.

After 1 year, another 3 recurrences were found. Therefore, the final rate of fissure healing was $92.5 \%$, with $7.5 \%$ of recurrence. Incontinence was seen in 5\% (6 patients), and occasional to flatus in all cases.

Table IV shows the mean MRP and MSP before and after treatment. MRP was reduced in $32.7 \%$, being directly related to a higher percentage of fissure healing. MRP after 1 year in healed patients was $75.65 \mathrm{mmHg}$, whereas it was 112.85 $\mathrm{mmHg}$ in patients with fissure recurrence, and this difference was statistically significant $(p<0.001)$. There were no significant differences in MSP. Therefore, in terms of healing, MRP before open sphincterotomy was similar to MRP in patients with recurring fissures, while MRP in the control group was similar to that of healed patients. On a multivariate analysis, fissure recurrence or persistence was related to the presence of a sentinel hemorrhoid and to having had the fissure for over 12 months. No relationship was found between the other variables and healing.

As far as incontinence is concerned, MRP in incontinent patients was lower than that of continent patients $(55 \pm 7$ mmHg versus with $80.7 \pm 21 \mathrm{mmHg}$ ), and this difference was statistically significant $(\mathrm{p}<0.001)$. The difference in MSP between incontinent patients $(157.4 \pm 56.7 \mathrm{mmHg})$ and continent

Table IV. Mean resting (MRP) and squeeze (MSP) pressures at anal manometry

\begin{tabular}{lcc}
\hline & MRP & MSP \\
\hline Before treatment & $109 \pm 29$ & $200 \pm 79.5$ \\
2 months & $72.5 \pm 20.3$ & $178.6 \pm 73.4$ \\
6 months & $72 \pm 19.2$ & $185.7 \pm 68.3$ \\
1 year & $73.4 \pm 17.1$ & $188.2 \pm 60$ \\
\hline
\end{tabular}

The values are expressed as mean $\pm \mathrm{Sdm}$. patients $(176.7 \pm 68.4 \mathrm{mmHg})$ was not statistically significant. Of all the variables analyzed, only age $>50$ years was associated with incontinence. All incontinent patients were older than 50 . Nine out of 20 patients older than 50 presented postoperative disturbances of continence, whereas no case of incontinence was reported in patients younger than 50 .

\section{DISCUSSION}

$\mathrm{CAF}$ is one of the main proctological disorders encountered in consulting rooms, due to its high prevalence and the great discomfort involved. It may be wrongly diagnosed as hemorrhoids and perianal fistula. Despite the lesion's small size, it causes great discomfort and pain, which sometimes becomes incapacitating $(1,2)$.

As occurred in our series, CAF is reported to affect men and women alike, though more frequently men aged 20 to 40 years $(1,7)$. The three typical symptoms of presentation are: constipation, bleeding, and proctalgia, with the latter being the main symptom. Clinical examination may require local anesthesia for local pain. The anal fissure is most often located to the mild posterior line, and frequently a "sentinel hemorrhoid or polyp" may be seen on it $(1,7)$. Ninety per cent of acute fissures respond to conservative treatment with a fibre-rich diet and warm sitz baths. However, many persist for several weeks and may become chronic.

Identification of the etiology or predisposing factors may help prevent or reduce the high incidence of this disorder. Many studies have suggested various etiopathogenic theories for anal fissure, and so a multifactorial origin for this condition (constipation, diarrhea, local vascular or infectious conditions, idiopathic, etc) is most likely. Thus, in many cases the cause is not found $(1,7)$. However, it is believed that hypertonia of the internal anal sphincter associated with increased pressure following a voluntary contraction plays an important role $(4,5,8)$. For this reason, medical-surgical procedures to reduce the pressure of the internal anal sphincter have been used for fissure healing.

A great variety of therapeutic methods for the treatment of CAF have been proposed when conservative treatment fails: non-surgical treatments, as topical treatments such as botulinum toxin (9-14), nitrate preparations $(8,15)$, and nifedipine (16); and surgical treatments such as anal dilatation (17,18), sphincterotomy (19-22), and advanced flap (20). All these techniques aim at a high rate of healing in association with a low morbidity rate. Internal lateral sphincterotomy has been proven the procedure of choice in various comparative studies, since it exhibits the highest rate of healing associated with the lowest indexes of incontinence.

Two types of internal lateral sphincterotomy have been widely discussed in the literature: open sphincterotomy, first described in 1951 by Eisenhamer (23), and closed or subcutaneous sphincterotomy, first described in 1971 by Notaras (24), with varying rates of recurrence (0-10\%) and incontinence $(0-66 \%)(1,3,6,14,17,25-27)$. Only two prospective randomized studies $(28,29)$ compared these two surgical techniques, and no statistically significant differences were found to dispel the ideal option. 
The results obtained in our study are comparable to those published for the closed or subcutaneous technique, with a healing rate higher than $90 \%$, and a sporadic incontinence rate higher than $6 \%$.

Recurrence is closely related to persistence of sphincter spasm or its manometric translation into a persistently raised MRP, which is a fundamental etiopathogenic mechanism of fissures $(4,5,8)$. Patients with fissure recurrence or persistence exhibited an MRP after open sphincterotomy $(112.85 \mathrm{mmHg})$ that was similar to their previous MRP $(109 \pm 29 \mathrm{mmHg})$, contrary to patients in whom the fissure healed, whose MRP after surgery was $75.65 \mathrm{mmHg}$, with a decrease in MRP of 33.6\%.

We have found several clinical factors that relate to recurrence, such as the presence of a sentinel hemorrhoid or polyp, and the duration of symptoms for more than 12 months. As a matter of fact, both factors usually suggest chronic advanced disease associated with difficulties in ephitelization.

Incontinence in our study was related to a lower MRP due to an extensive section of the internal anal sphincter. MSP on the other hand remained unchanged, since its value mostly depends on the external anal sphincter, which by no means is altered with this technique. It should be noted that during follow-up the rate of incontinence initially reported decreased progressively over time, and so it did temporary incontinence, which was also reflected manometrically.

Various studies have pointed out the advantages of open sphincterotomy under local anesthesia, since results obtained in terms of healing and postoperative complications are similar to those obtained using other types of anesthesia. This technique has the added advantage of not requiring hospital admission, an operating theatre, or preoperative studies. Moreover, the lower morbidity associated with local anesthesia as compared to general or spinal anesthesia gives the patient a higher degree of satisfaction and comfort $(21,28,29)$. The portion of the internal anal sphincter divided under local anesthesia tends to be smaller, due to the relative difficulty in identifing the sphincter and to the lesser relaxation of the perineum in comparison to other types of anesthesia, which results in fewer disturbances of continence (30).

The results of our study confirm these facts, and we also obtained long-term healing and morbidity rates similar to those obtained with other techniques. Therefore, this technique may be considered a suitable and effective treatment for this condition.

\section{REFERENCES}

1. Oh C, Divino CM, Steinhagen RM. Anal fissure: 20-year experience. Dis Colon Rectum 1995; 38: 378-82.

2. Sailer M, Bussen D, Debus ES, Fuchs KH, Thiede A. Quality of life in patients with benign anorectal disorders. Br J Surg 1998; 85: 1716-9.

3. Hawley P. The treatment of chronic fissure in ano: a trial of methods. Br J Surg 1969; 56: 915-7.

4. Mc Namara MJ, Percy JP, Fielding IR. A manometric study of anal fissure treated by subcutaneous lateral internal sphincterotomy. Ann Surg 1990; 211: 235-8.

5. Xynos E, Tzortzinis A, Chrysos E, et al. Anal manometry in patients with fissure-in-ano before and after internal sphincterotomy. In J Colorect Dis 1993; 8: 125-8

6. Nelson RL. Meta-analysis of operative techniques for fissure-in-ano.
Dis Colon Rectum 1999; 42: 1424-8.

7. Sales R, Martínez P, Lóbez T, Culell P, Fons P, Ballús LL, et al. Cirugía de la fisura anal crónica: resultados a largo plazo. Cir Esp 2000; 68: 467-70.

8. Evans JE, Luck A, Hewett P. Glyceryl trinitate vs lateral sphincterotomy for chronic anal fissure. Prospective, randomized trial. Dis Colon Rectum 2001; 44: 93-7.

9. Maria G, Brisinda G, Bentivoglio AR, et al. Botulinum toxin injections in the internal anal sphincter for the treatment of chronic anal fissure. Long-term results aftre two different dosage regimens. Ann Surg 1998; 228: 664-9.

10. González P, Pérez F, Legaz ML, et al. Tratamiento de la fisura anal con toxina botulínica. Gastroenterol Hepatol 1999; 22: 163-6.

11. Mínguez M, Melo F, Espí A, et al. Therapeutics effects of different doses of botulinum toxin in chronic anal fissure. Dis Colon Rectum 1999; 42: 1016-21.

12. Brisinda G, Maria G, Bentivoglio AR, et al. A comparison of injections of botulinum toxin and topical nitroglycerin ointment for the treatment of chronic anal fissure. N Engl J Med 1999; 341: 65-9.

13. Maria G, Brisinda G, Bentivoglio AR, et al. Influence of botulinum toxin site of injections on healing rate in patients with chronic anal fissure. Am J Surg 2000; 179: 46-50.

14. Brisinda G, Maria G, Sganga G, et al. Effectiveness of higher doses of botulinum toxin to induce healing in patients with chronic anal fissures. Surgery 2002; 131: 179-84.

15. Richard CS, Gregoire R, Plewes EA, et al. Internal sphincterotomy is superior to topical nitroglycerin in the treatment of chronic anal fissure: results of a randomized, controlled trial by the Canadian Colorectal Surgical Trials Group. Dis Colon Rectum 2000; 43: 1048-57.

16. Brisinda G, Maria G. Oral nifedipine reduces resting anal pressures and heals chronic anal fissure. Br J Surg 2000; 87: 251.

17. Olsen J, Mortensen PE, Krogh I, et al. Anal sphincter function after treatment of fissure-in-ano by lateral subcutaneous sphincterotomy versus anal dilatation. A randomized study. Int J Colorectal Dis 1987; 2: $155-7$.

18. Weaver RM, Ambrose NS, Alexander-Williams J, Keighley MR. Manual dilatation of the anus vs. lateral subcutaneous sphincterotomy in the treatment of chronic fissure-in-ano. Results of a prospective, randomized, clinical trial. Dis Colon Rectum 1987; 30: 420-3.

19. Abcarian H. Surgical correction of chronic anal fissure: results of lateral internal sphincterotomy vs. fissurectomy-midline sphincterotomy. Dis Colon Rectum 1980; 23: 31-6.

20. Leong AF, Seow-Choen F. Lateral sphincterotomy compared with anal advancement flap for chronic anal fissure. Dis Colon Rectum 1995; 38: 69-71.

21. García-Aguilar J, Belmonte C, Wong WD, et al. Open vs. closed sphincterotomy for chronic anal fissure: long-term results. Dis Colon Rectum 1996; 39: 440-3.

22. Argov S, Levandovsky O. Open lateral sphincterotomy is still the best treatment for chronic anal fissure. Am J Surg 2000; 179: 201-2.

23. Eisenhamner S. The surgical correction of chronic anal (sphinteric) contracture. S Afr Med J 1951; 25: 486-9.

24. Notaras MJ. Lateral subcutaneous sphincterotomy for anal fissure-a new technique. Proc R Soc Med 1969; 62: 713.

25. Saad AM, Omer A. Surgical treatment of chronic fissure-in-ano: a prospective randomised study. East Afr Med J 1992; 69: 613-5.

26. García-Aguilar J, Belmonte C, Pérez JJ, et al. Incontinence after lateral internal sphincterotomy. Anatomic and functional evaluation. Dis Colon Rectum 1998; 41: 423-7.

27. Nyam DC, Pemberton JH. Long-term results of lateral internal sphincterotomy for chronic anal fissure with particular reference to incidence of fecal incontinence. Dis Colon Rectum 1999; 42: 130610 .

28. Kortbeek JB, Langevin JM, Khoo RE, Heine JA. Chronic fissure-inano: a randomized study comparing open and subcutaneous lateral internal sphincterotomy. Dis Colon Rectum 1992; 35: 835-7.

29. Boulos PB, Araujo JG. Adequate internal sphincterotomy for chronic anal fissure: subcutaneous or open technique? Br J Surg 1984; 71: 360-2.

30. Simkovic D, Smejkal K, Hladík P. Evaluación de los efectos de la esfinterotomía en los enfermos tratados por fisura anal crónica. Rev Esp Enferm Dig 2000; 92 (6): 399-401. 


\title{
Esfinterotomía lateral interna abierta con anestesia local como gold standard en el tratamiento de la fisura anal crónica. Estudio prospectivo clínico y manométrico a largo plazo
}

\author{
A. Sánchez Romero, A. Arroyo Sebastián, F. Pérez Vicente, P. Serrano Paz, F. Candela Polo, A. Tomás Gómez, \\ D. Costa Navarro, A. Fernández Frías y R. Calpena Rico
}

Servicio de Cirugía General y Aparato Digestivo. Hospital General Universitario. Elche. Alicante

\section{RESUMEN}

Introducción: la fisura anal crónica sigue siendo uno de los problemas proctológicos más frecuentes e incapacitantes en la población occidental actual. La esfinterotomía lateral interna abierta es una de las opciones terapéuticas descritas y aceptadas como tratamiento de elección de la fisura anal crónica, ya que reduce la hipertonía esfinteriana (mecanismo etiopatogénico fundamental de la fisura), permitiendo por tanto, disminuir la proctalgia y así la curación de la fisura.

Material y métodos: realizamos un estudio prospectivo de 120 pacientes intervenidos por fisura anal crónica con esfinterotomía lateral interna abierta con anestesia local (20 cc mepivacaína al 2\%) tratados ambulatoriamente en la consulta de la Unidad de Proctología entre los años 1998-2001. No se requirió estudios preoperatorios, preparación con enemas, profilaxis antibiótica, accesos venosos, ingreso ni observación hospitalaria. Los pacientes fueron revisados a la $1^{\underline{a}}$ semana, $2^{\circ}$ mes, $6^{\circ}$ mes y al año.

Resultados: complicaciones precoces ( $1^{\underline{a}}$ semana): 3 hematoma-equimosis de la herida (2,5\%), 3 hemorragias autolimitadas $(2,5 \%)$. No encontramos trombosis hemorroidales, fístulas, abscesos perianales ni mortalidad. Complicaciones tardías (2ㅇ mes): 9 pacientes con incontinencia $(7,5 \%)$ y 3 pacientes $(2,5 \%)$ con recurrencia de la fisura. $\mathrm{Al} 6^{\circ}$ mes, la incontinencia disminuyó al $5 \%$ (6 pacientes), y aparecieron 3 pacientes más con recurrencia de la fisura (2,5\%). Al año se mantuvo la tasa de incontinencia del $5 \%$ (a gases y líquidos) y aparecieron otros 3 pacientes con recurrencia de la fisura (2,5\%). Recurrencia global del 7,5\%.

Los hallazgos en la manometría fueron, PMB (presión máxima basal) pre-tratamiento similar a la $\mathrm{PMB}$ en pacientes con recurrencia de la fisura, así como la PMB del grupo control similar a la PMB de pacientes con curación. La PMB en pacientes incontinentes fue más baja que la PMB en pacientes continentes ( $55 \pm 7$ frente a $80,7 \pm 21$ ). La diferencia entre la PMCV (presión máxima de contracción voluntaria) en pacientes incontinentes y pacientes continentes no fue estadísticamente significativa.

Conclusiones: la esfinterotomía lateral interna abierta con anestesia local tiene una tasa de curación a largo plazo y unos índices de morbilidad equiparables a otras técnicas, por lo que puede ser considerada como un tratamiento adecuado y eficaz para esta patología.

Palabras clave: Fisura anal crónica. Esfinterotomía. Manometría.

\section{INTRODUCCIÓN}

La fisura anal crónica sigue siendo uno de los problemas proctológicos más frecuentes en la población occidental actu- al, que en ocasiones llega a condicionar la calidad de vida del paciente que la padece $(1,2)$. Es por ello, que el tratamiento rápido y eficaz de esta patología se convierte en prioritario en las consultas de proctología y cirugía general $(1,3)$.

La etiología de esta patología es controvertida, pero se reconoce que el espasmo del esfínter anal interno juega un papel fundamental en la patogénesis; hablaríamos pues de un círculo vicioso: fisura-espasmo del esfinter anal interno-dolor $(4,5)$.

De acuerdo con esto, la esfinterotomía lateral interna (ELI) ha sido ampliamente aceptada como el tratamiento de elección de la fisura anal crónica, ya que reduce la hipertonía esfinteriana, permitiendo disminuir la proctalgia y así la curación de la fisura (6). Con esto, la ELI abierta realizada con anestesia local se convierte en una técnica rápida y eficaz para el tratamiento de la fisura anal crónica.

Por ello, hemos estudiado las ELI abiertas realizadas con anestesia local ambulatoriamente en nuestra Unidad de Coloproctología, para evaluar nuestros resultados en términos de curación y complicaciones en el tratamiento de la fisura anal crónica.

\section{MATERIAL Y MÉTODOS}

Realizamos un estudio prospectivo de 120 pacientes, intervenidos de fisura anal crónica entre septiembre de 1998 y septiembre del 2001, en la Unidad de Coloproctología del Hospital General Universitario de Elche. La esfinterotomía fue realizada tras la obtención de un consentimiento informado.

El diagnóstico de fisura anal crónica, se estableció mediante exploración clínica (visualización), siendo necesario un tiempo mayor a 1 mes con tratamiento médico (dieta pobre en residuos, analgésicos y baños de asiento) sin curación, para ser considerada como crónica e incluida en el estudio. Se recogieron datos sobre la edad, el sexo, síntomas, hábito intestinal, hallazgos en la exploración y valores manométricos de los pacientes, previos a la intervención. Las características de la población estudiada fueron: edad media de presentación: 40,45 años (rango: 21-74), 42 mujeres (35\%) y 78 hombres (65\%); duración de los síntomas 17,60 meses (rango: 1-70). Destacamos el estreñimiento, la proctalgia y la rectorragia como síntomas principales en la presentación 
clínica de esta patología, ocurriendo en más del $60 \%$ de los pacientes (Tabla I).

Tabla I. Características de los pacientes, síntomas y exploración anal antes del tratamiento

\begin{tabular}{lc}
\hline Edad media & 40,45 años $(21-74)$ \\
Sexo (femenino/masculino) & $42(35 \%) / 78(65 \%)$ \\
Duración de los síntomas (meses) & $17,60(1-70)$ \\
Localización de la fisura & \\
$\quad$ Línea media posterior & $84(70 \%)$ \\
$\quad$ Línea media anterior & $27(22,5 \%)$ \\
$\quad$ Ambos & $9(7,5 \%)$ \\
Tag cutáneos & $84(70 \%)$ \\
Proctalgia & $108(90 \%)$ \\
Estreñimiento & $80(67 \%)$ \\
Rectorragia & $102(85 \%)$ \\
Constipación & $84(70 \%)$ \\
Prurito & $60(50 \%)$ \\
Antecedentes de cirugía anal & $6(4,7 \%)$ \\
Hipertonía anal & \\
Leve & $18(15 \%)$ \\
Moderada & $72(60 \%)$ \\
Inexplorable & $30(25 \%)$ \\
\hline
\end{tabular}

Los criterios de exclusión fueron: patologías anales asociadas (incontinencia, estenosis, absceso, fístula y hemorroides), pacientes con otras patologías asociadas (enfermedad inflamatoria intestinal, sida, tuberculosis, enfermedad de transmisión sexual e inmunodepresión), terapia anticoagulante y alergia a anestésicos locales.

Todos los pacientes fueron intervenidos por 3 cirujanos expertos en cirugía coloproctológica. El procedimiento se realizó usando un método uniforme colocando al paciente en posición de navaja. Los pacientes sólo fueron monitorizados con pulsioxímetro, no requiriendo estudios preoperatorios, preparación con enemas, antibióticos ni accesos intravenosos. Se utilizó anestesia local (20 cc mepivacaína $2 \%$ ), usando una aguja $25 \mathrm{G}$, infiltrando la piel, plano interesfinteriano, esfínter interno y submucosa, del lado derecho e izquierdo, y el lecho de la fisura.

La técnica utilizada fue la esfinterotomía lateral interna abierta: se expone la región anal derecha con un retractor anal, y se hace una incisión de la piel de 1-2 cm en el espacio interesfinteriano. La mucosa anal se separa del esfínter interno, siempre por debajo de la línea pectínea. Se diseca el espacio interesfinteriano, separando los esfínteres. Se secciona el esfínter interno distal bajo visión directa con elec- trobisturí. La incisión de la piel no se cierra y se realiza presión directa durante 5 minutos.

Los pacientes no requirieron ingreso ni observación hospitalaria; al alta se les dio instrucciones concernientes a una dieta rica en residuos, analgésicos y baños de asiento con agua tibia.

Se revisaron a los pacientes en nuestra consulta de coloproctología a la $1^{\mathrm{a}}$ semana, $2^{\circ}$ mes, $6^{\circ}$ mes y $1^{\text {er }}$ año; se recogió información acerca de los síntomas, hábito intestinal, hallazgos en la exploración y valores manométricos postoperatorios, así como complicaciones tempranas y tardías, curación/recurrencia de la fisura. La curación de la fisura fue definida como la epitelización de la fisura y la ausencia de síntomas. La continencia se determinó con el Cleveland Score (Tabla II).

La manometría anal se realizó con un sistema de perfusión de agua (Ardorfer Medical Specialities Inc., Greendale, WI) con un catéter de 6 luces (diámetro externo de 4 $\mathrm{mm})$. Se midieron la presión máxima basal (PMB) y la presión máxima con la contracción voluntaria (PMCV). Los resultados fueron comparados con rangos normales de pacientes sanos de nuestro laboratorio: $\mathrm{PMB}=66 \pm 23 \mathrm{mmHg}$ y $\mathrm{PMCV}=164 \pm 60 \mathrm{mmHg}$ (grupo control). El análisis estadístico de la manometría fue comparado usando el test de Student.

\section{RESULTADOS}

La localización de la fisura más frecuente fue a las $12 \mathrm{~h}$ en posición genupectoral (70\%), siendo en la mayoría única, encontrando sólo en 7 pacientes más de una fisura. Destacó en la exploración física la alta incidencia de hipertonía esfinteriana asociada -leve: 18 pacientes $(15 \%)$, moderada 72 pacientes $(60 \%)$ e inexplorable 30 pacientes $(25 \%)-$, y la presencia de un "pólipo o hemorroide centinela" sobre la fisura en 84 pacientes (70\%) (Tabla I).

Las complicaciones y resultados del tratamiento aparecen en la tabla III. En la revisión de la $1^{\text {a }}$ semana, podemos observar un sangrado autolimitado de la herida en 3 pacientes $(2,5 \%)$ y equimosis de la herida en otros 3 pacientes $(2,5 \%)$. No hubo pacientes con absceso anal, fístula perianal, trombosis hemorroidal ni retención urinaria. Tampoco hubo mortalidad postoperatoria ni pacientes que requirieran ingreso hospitalario por complicación quirúrgica.

En la revisión del $2^{\circ}$ mes, encontramos persistencia o recidiva de la fisura en 3 pacientes $(2,5 \%)$. Con respecto a la in-

Tabla II. Cleveland Score

\begin{tabular}{lcccc}
\hline Tipo de incontinencia & Nunca & Raro & A veces & Usualmente \\
\hline Heces sólidas & 0 & 1 & 2 & 3 \\
Heces líquidas & 0 & 1 & 2 & 3 \\
Gas & 0 & 1 & 2 & 4 \\
Pañal & 0 & 1 & 2 & 3 \\
Alteración del estilo de vida & 0 & 1 & 2 & 3 \\
\end{tabular}

Nunca, ningún episodio de incontinencia; raro menos de un episodio por mes; a veces, más de un episodio; usualmente uno o más episodios por semana, pero menos de uno al día; siempre, más de un episodio al día. El rango será desde 0 (continencia normal), hasta un máximo de 20 (máxima incontinencia con máximo disconfort en el estilo de vida). 
Tabla III. Complicaciones y resultados del tratamiento

\begin{tabular}{|c|c|}
\hline Equimosis & $3(2,5 \%)$ \\
\hline Hemorragia & $3(2,5 \%)$ \\
\hline Absceso anal o fístula & $0 \%$ \\
\hline $\begin{array}{l}\text { Trombosis hemorroidal } \\
\text { Incontinencia }\end{array}$ & $0 \%$ \\
\hline $2^{\circ}$ mes & $\begin{array}{r}9(7,5 \%) \ldots . \text { a líquidos } 3(2,5 \%) \\
\\
\text { a gases } 2(1,66 \%) \\
\text { a heces } 4(3,33 \%)\end{array}$ \\
\hline $6^{\circ}$ mes & $6(5 \%)$ \\
\hline $1^{\circ}$ año & $6(5 \%)$ \\
\hline \multicolumn{2}{|l|}{ Recurrencia } \\
\hline $2^{\circ}$ mes & $3(2,5 \%)$ \\
\hline $6^{\circ}$ mes & $3(2,5 \%)$ \\
\hline $1^{\circ}$ año & $3(2,5 \%)$ \\
\hline Total & $9(7,5 \%)$ \\
\hline
\end{tabular}

continencia encontramos 3 pacientes $(2,5 \%)$ con incontinencia a líquidos, 2 pacientes $(1,66 \%)$ con incontinencia esporádica a gases, y $4(3,33 \%)$ con incontinencia ocasional a heces. La tasa total de incontinencia fue del 7,5\%. En la revisión del $6^{\circ}$ mes, encontramos a 3 pacientes más $(2,5 \%)$ con recidiva de la fisura. De los pacientes con incontinencia en la revisión del $2^{\circ}$ mes, 3 pacientes refirieron desaparición de la misma.

En la revisión del año, aparecieron 3 recidivas más. Por tanto, la tasa final de curación de la fisura fue del 92,5\%, y la tasa de recidiva del 7,5\% (9 pacientes). La tasa final de incontinencia fue del 5\% (6 pacientes), tratándose en todos los casos de incontinencia ocasional a gases.

En la tabla IV, se muestran las medias de la PMB y PMCV previas al tratamiento y posteriores al mismo. La PMB previa al tratamiento fue de $109 \pm 29$ comparado con el grupo control; después del tratamiento, disminuyó a 72,5 al $2^{\circ}$ mes, 72 al $6^{\circ}$ mes y 73,4 al año. El porcentaje de disminución de la PMB al año fue del 32,7\%, lo cual está directamente asociado con un mayor porcentaje de curación de la fisura. La PMB al año en pacientes curados fue de 75,65 y de 112,85 en pacientes con recidiva de la fisura, siendo la diferencia estadísticamente significativa $(p<0,001)$. No hubo diferencias significativas en la PMCV. Así pues, en términos de curación, la PMB pre-tratamiento fue similar a la $\mathrm{PMB}$ en pacientes con recurrencia de la fisura, así como la PMB del grupo control similar a la PMB de pacientes con curación. En el análisis multivarianza, la recidiva o persistencia de la fisura tuvo relación con la presencia de una hemorroide centinela y un tiempo mayor de 12 meses de evolución de la fisura. No se encontró relación con otras variables previas al tratamiento y la curación.

Tabla IV. Medias de PMB y PMCV

\begin{tabular}{lcc}
\hline & $P M B$ & $P M C V$ \\
\hline Previo al tratamiento & $109 \pm 29$ & $200 \pm 79,5$ \\
$2^{\circ}$ mes & $72,5 \pm 20,3$ & $178,6 \pm 73,4$ \\
$6^{\circ}$ mes & $72 \pm 19,2$ & $185,7 \pm 68,3$ \\
$1^{\text {er }}$ año & $73,4 \pm 17,1$ & $188,2 \pm 60$ \\
\hline
\end{tabular}

Los valores son presentados como medias \pm desviación estándar $(\mathrm{mmHg} \pm$ desviación estándar).
En términos de incontinencia, la PMB en pacientes incontinentes fue más baja que la $\mathrm{PMB}$ en pacientes continentes $(55 \pm 7$ frente a $80,7 \pm 21)$, siendo esta diferencia estadísticamente significativa $(\mathrm{p}<0,001)$. La diferencia entre la $\mathrm{PMCV}$ en pacientes incontinentes $(157,4 \pm 56,7)$ y pacientes continentes $(176,7 \pm 68,4)$ no fue estadísticamente significativa.

De todas las variables previas al tratamiento analizadas, sólo la edad $>50$ años estuvo asociada con la incontinencia. De los 20 pacientes mayores de 50 años de nuestra serie, 9 de ellos fueron incontinentes. Ningún paciente menor de 50 años presentó incontinencia.

\section{DISCUSIÓN}

La fisura anal crónica continúa siendo uno de los problemas proctológicos más importantes en las consultas de medicina general, dada su alta prevalencia y gran discomfort. Frecuentemente es erróneamente diagnosticada como hemorroides, fístula perianal, etc., con la consecuente no curación y persistencia del problema. A pesar de su apariencia banal por tratarse de una lesión de pequeño tamaño, causa importantes molestias y dolor, en ocasiones incapacitante y desproporcionado a su tamaño $(1,2)$.

Al igual que en nuestra serie, la bibliografía muestra que la fisura anal crónica puede afectar a ambos sexos, siendo más frecuente en hombres y en el grupo de población de entre 20-40 años $(1,7)$. La triada clínica típica de presentación es: estreñimiento, rectorragia y proctalgia, siendo este último su síntoma princeps. A la exploración, que en ocasiones debe ser bajo anestesia local por el dolor local, observamos la fisura anal situada más frecuentemente en rafe posterior, siendo muy frecuente apreciar sobre ella una "hemorroide o pólipo centinela" $(1,7)$. El 90\% de las fisuras agudas responden al tratamiento conservador con dieta rica en fibra y baños de asiento; sin embargo, muchas persisten varias semanas, llegando a convertirse en crónicas.

La identificación de la etiología o factores predisponentes, puede ayudarnos a prevenir o reducir la alta incidencia de esta patología. Muchos estudios han propuesto varias teorías etiopatogénicas de la fisura anal, pudiendo por tanto, dilucidar el probable origen multifactorial de esta patología (estreñimiento, diarrea, procesos infecciosos o vasculares locales, idiopático). Sin embargo, se cree que la hipertonía del esfínter anal interno asociada a incrementos en la presión tras la contracción voluntaria juegan un importante papel $(4,5,8)$. Por esta razón, se han usado procedimientos médico-quirúrgicos que reducen la presión del esfínter anal interno para la curación de la fisura.

Se han propuesto una gran variedad de métodos terapéuticos para el tratamiento de la fisura anal crónica tras el fracaso del tratamiento conservador: tratamientos no quirúrgicos, como la toxina botulínica (9-14), los derivados del óxido nítrico $(8,15)$ y el nifedipino $(16)$, y tratamientos quirúrgicos como las dilataciones $(17,18)$, la esfinterotomía (19-22) y el avance del flap (20). En todos se busca una tasa de curación alta con bajos índices de morbimortalidad asociada. De todos ellos, la esfinterotomía lateral interna ha lle- 
gado a ser el procedimiento de elección en diversos estudios comparativos que se han hecho, por presentar la tasa de curación más alta, asociado a tasas de incontinencia bajas.

Existen dos tipos de esfinterotomía lateral interna ampliamente discutidos en la bibliografía: la abierta, descrita en 1951 por Eisenhamer (23), y la cerrada o subcutánea, descrita en 1971 por Notaras (24), con índices muy variables de recidiva $(0-10 \%)$ e incontiencia $(0-66 \%)$ publicados $(1,3,6$, 14,17,25-27). Sólo existen dos estudios prospectivos randomizados $(28,29)$ comparando ambas técnicas quirúrgicas sin encontrar diferencias estadísticamente significativas que permitan establecer la opción ideal.

En nuestro estudio encontramos resultados comparables a los publicados con la técnica cerrada o subcutánea, con índices de curación $>90 \%$ y con tasas de incontinencia esporádica $<6 \%$.

La recidiva está intimamente relacionada con la persistencia del espasmo del esfínter o su traducción manométrica en PMB persistentemente elevadas, mecanismo etiopatogénico fundamental de la fisura $(4,5,8)$. Los pacientes con recidiva o persistencia de la fisura mostraron una PMB post-tratamiento $(112,85)$ similar a la PMB previa $(109 \pm 29)$, a diferencia de los pacientes con curación de la fisura cuya PMB posttratamiento fue de 75,65 , con una reducción de la PMB en un $33,6 \%$.

Igualmente, encontramos unos factores clínicos preterapéuticos relacionados con una mayor recidiva (presencia de hemorroide centinela y duración de la enfermedad más de 12 meses), que indican una mayor "cronificación" de la fisura y donde la dificultad local de re-epitelización de la lesión es mayor.
La incontinencia en nuestro estudio está relacionada con PMB bajas, causadas por una excesiva sección del esfínter anal interno. Sin embargo, la PMCV no se altera y por tanto no se relaciona con la incontinencia, ya que esta es dependiente principalmente del esfínter anal externo sobre el cual no se actúa durante la cirugía. Destacamos que durante el seguimiento los índices de incontinencia descritos inicialmente disminuyen progresivamente con el tiempo, tratándose de esta manera de una incontinencia recuperable que queda reflejada manométricamente.

Por otra parte, diversos estudios destacan las ventajas de la esfinterotomía abierta bajo anestesia local, ya que presenta resultados equiparables en términos de curación y complicaciones postoperatorias a las obtenidas con otros tipos de anestesia, añadidas a las ventajas de la ausencia de hospitalización, quirófano ni estudios preoperatorios, junto a la menor morbilidad de la anestesia local frente a la general o raquídea, que proporciona así un mayor grado de satisfacción y confort por parte del paciente $(21,28,29)$. Otras ventajas de la anestesia local, es que dada la mayor dificultad técnica de identificación del esfínter anal interno, y la menor relajación del periné con anestesia local respecto a otras anestesias, se produce una reacción limitada, con lo que la incontinencia es menor bajo este tipo de anestesia (30).

Los resultados de nuestro estudio corroboran dicha afirmación, además de obtener tasas de curación a largo plazo y unos índices de morbilidad equiparables a otras técnicas, por lo que puede ser considerada como un tratamiento adecuado y eficaz para esta patología. 